\title{
Personal or Remote interaction? BANKING THE UNBANKED IN SOUTH AFRICA
}

Johan Coetzee

Department of Economics, University of the Free State

\begin{abstract}
The Financial Sector Charter (FSC) requires South African retail banks to provide retail products and services to the rural-based unbanked. The challenge is deciding whether or not banking the unbanked must be pursued through personal or remote channels. This study considers the challenge facing the four largest South African retail banks. It investigated trends in servicing this market since the effective date of the Charter. It found that banks are currently using an integrated approach combining personal and remote interaction and emphasising the promotion of financial literacy. It remains to be seen whether this approach truly adds value for the unbanked. It is recommended that further research be done to establish exactly what the behavioural characteristics of the unbanked are over a period of continuous use of bank products and services.
\end{abstract}

JEL G2

\section{1 \\ Introduction}

The South African financial sector has committed itself to promoting Black Economic Empowerment (BEE) by voluntarily developing the Financial Sector Charter (FSC). The FSC was signed in October 2003, to be effective between 1 January 2004 and 31 December 2014 (FSC, 2003: 6). The Charter focuses on six pillars, namely human resources development, procurement and enterprise development, ownership and control, access to financial services, empowerment financing and corporate social investment. The dominant theme of the Charter is the promotion of BEE, primarily by ensuring that the financial sector in general pursues business practices that will ultimately promote the financial inclusion of the previously disadvantaged. This is clearly evident from the opening page of the Charter (FSC, 2003: 1), which states:

We, the parties to this charter, therefore commit ourselves to actively promoting a transformed, vibrant, and globally competitive financial sector that reflects the demographics of South Africa, and contributes to an establishment of an equitable society by effectively providing accessible financial services to black people...

Achieving the aims of the Charter poses challenges to the parties that endorse it. For example, the "access to financial services" pillar (FSC, 2003: 9) requires banks to provide first-order retail financial services to the predominantly rural and so far largely unbanked mass market. For banks to do this, they must be sensitive to ever-changing technologies and must ensure that multi-channel electronic banking facilities, such as the Internet, telephone, automated teller machines (ATMs) and selfservice-terminals (SSTs), ${ }^{1}$ not only provide innovative access to formal mainstream clients, but also address the unique characteristics of the rural unbanked. What makes this task so daunting is that the competitive banking environment is synonymous with innovative 
ideas that are constantly copied by competitors (Greenland, 1994: 22). Banks therefore need to be innovative and remain relevant to client needs. The dynamics surrounding the unbanked are, therefore, unique. When servicing the unbanked, banks must decide whether to adopt a remote or personal interaction approach. While innovation is vital, banks must ensure accessibility and promote basic financial literacy.

\section{2}

\section{Identification of the problem and the research objectives}

In view of the FSC's requirement that banks must focus on providing innovative and accessible means to bank the rural mass market, an important consideration is what type of interaction should take place - personal, remote, or a combination of these? Adopting a remote strategy relies on the use of electronic channels to interface with clients, while a personal strategy relies on some form of human faceto-face interaction. Banks currently use both approaches in their existing delivery channel strategy, but the Finscope surveys (Finscope 2003; Finscope South Africa, 2006) indicate that the rural mass market tends to lack adequate levels of financial literacy and competence in the use of financial products and services. So, while a remote strategy may be suitable from a cost and logistical perspective, the question is whether this market would benefit from a financial literacy point of view, given that personal human interaction provides bank staff with an opportunity to explain how bank products and services work. Such interactions and opportunities appear to constitute a type of relationship between the bank (through its client-facing staff) and the (previously) unbanked client that seems to be beneficial.

The problem is that a relationship-based approach is commonly associated only with high net worth clients, where the relationship enables the bank to identify cross-selling opportunities - clearly the unbanked do not fall into this category. Because the FSC requires banks to educate the unbanked, some form of personal face-to-face interaction is, however, required. How then should banks manage this dilemma? As is discussed in the next section, banks must balance and manage two extremes: banking the unbanked, who are typically low net worth clients, and at the same time promoting financial literacy. The article pursues this point and proposes that, although the banks would not benefit from using a relationship-based approach in the accepted sense, providing accessibility and financial education requires the bank to have at least some aspects of face-to-face human interaction in place when dealing with the unbanked. In exploring the dilemma, the four largest retail banks (the Big4) in South Africa, namely ABSA, First National Bank (FNB), Nedbank and Standard Bank, are considered.

The study investigates the implications of the FSC for delivery channel strategy and, in particular, for how the Big4 banks have adapted their distribution channel strategy, particularly since the inception of the FSC on 1 January 2004. To date, no study has investigated the practical implications of the FSC for banks, and more especially, for how banks have adapted their strategies to address the requirements of the FSC. Such a study is vital, as all four major banks have committed themselves to exceeding the targets set by the FSC (ABSA, 2005: 18; FirstRand, 2005: 6; Nedbank Group, 2006b: 9; Standard Bank of South Africa, 2005: 17). This article considers only the "access to financial services" pillar of the FSC and its impact on the decision by the Big4 on how to interact with the unbanked.

Bearing this in mind, the specific objectives of the study are to

- establish whether a personal or remote relationship strategy is a better alternative in banking the rural unbanked; and

- identify how the Big4 South African retail banks currently service the rural unbanked and, in particular, establish whether they favour a personal or remote approach. 


\section{3}

\section{The FSC and the unbanked}

\subsection{Requirements regarding the accessibility of financial services}

The FSC requires financial institutions to improve access to affordable first-order retail financial services within the Living Standards Measure (LSM) 1-5 segments, including basic savings, transactional, insurance and low-income housing credit products (FSC, 2003: 9). In addition, the financial industry has committed itself to providing accessible physical and electronic infrastructure by 2008 and to contributing 0.2 per cent of post-tax profits to consumer education. This is designed to empower consumers, particularly the previously disadvantaged, to make more informed financial decisions about their finances and lifestyles (FSC, 2003: 10). The notion of the financial inclusion of the previously disadvantaged into the mainstream economic society is central to the FSC. ${ }^{2}$

Logistical considerations also form part of the Charter's requirements. For example, the Charter states that provision of first-order financial services must occur within a 20 kilometre radius of the nearest service point by 2008 (FSC, 2003:3). Financial institutions have therefore committed themselves to the eradication of discrimination in the provision of financial services to the previously disadvantaged (FSC, 2003: 10). The FSC also prescribes the provision of "financial literacy programmes in communities" by financial institutions (FSC, 2003: 13).

\subsection{The characteristics of the unbanked}

The Big4 have indicated that previous attempts to bank the unbanked have not been successful (Hawkins, 2004: 199; PWC, 2005: 18). This has resulted in competition from several non-bank institutions which have tried to capitalise on extensive distribution infrastructures to bank the unbanked (Hawkins, 2004: 200). These non-traditional providers have competitive advantages in areas such as brands, client bases, branch infrastructure and flexible trading hours (Feasibility, 2005: 95).
Finmark Trust (2005: 2) has indicated that consumers' financial literacy is an important prerequisite for the successful implementation of the FSC, in particular, the requirement that financial services should be accessible to the rural unbanked mass market. The distribution channels used by banks must be accessible and should, at the same time, empower the unbanked to make more informed financial decisions. Although addressing the needs of this sector is challenging, especially considering the vagueness associated with accessibility (Porteous, 2004: 47), the unbanked segment has been identified as potentially particularly profitable by the banks themselves. For example, ABSA has indicated that its Flexi-Banking line has in the past reported a return on equity higher than 200 per cent (ABSA, 2004: 121). It therefore appears that the profitability of the unbanked segment correlates favourably with the indication by South African banks that the retail segment is generally profitable, if not extremely profitable (PWC, 2005: 39).

Nevertheless, with almost one half of South African citizens unbanked and without access to any form of financial services in 2003 (Falkena et al., 2004: 80), the statistics available on the unbanked are somewhat restricted. The Finscope survey is regarded as the only recognised source of information regarding the characteristics of the previously unbanked. ${ }^{3}$ Their most noticeable characteristics are that, according to Falkena et al. (2004) and Finscope (2003: 1,3), they typically do not have any form of transactional account, tend to be less well educated, reside in informal (rural) areas and townships, are mostly black or coloured, and lack a steady cash flow. A large proportion of the unbanked have no formal evidence of any form of credit history and are not banking product literate. The 2006 Finscope survey indicated a serious lack of understanding regarding financial terminology (Finscope South Africa, 2006: 27). Interestingly, only 16 per cent of the respondents in the survey had never before heard of an ATM. The 2006 survey did, however, indicate a noticeable improvement in access. In particular, both the number of banked adults and bank usage by the LSM 1-5 segment has risen noticeably largely due to the uptake of the Mzansi account (see Finscope South Africa, 2006: 18, 20). 


\section{4}

\section{Interacting with the unbanked: distribution channel considerations}

A bank has two modes of interaction - personal (face-to-face interaction, typically through branches) and remote (where no face-to-face interaction exists, typically through electronic channels such as the Internet and ATMs). The dilemma for banks is to decide, within the prescriptions of the FSC, which of these two modes would be more beneficial to the unbanked market, whilst taking into account their low levels of financial literacy and generally poor level of understanding of how bank products and services function. This section provides an overview of these considerations, particularly from the perspective that a bank is able to gather information in varying degrees, depending on the mode of interaction it has with its client. Bearing in mind that a large proportion of the unbanked have in the past had limited or no exposure to a bank and its products and services, the unbanked generally do not have any prior financial history. This invariably restricts the available information that can be provided to a bank when it needs to assess the behavioural characteristics of an unbanked client.

\subsection{Gathering information in a relationship-based context}

Since the publicly available information on the unbanked is limited, banks themselves are expected to collect information that they use exclusively in their dealings with this segment. A bank is able to gather information on its clients by engaging in multiple interactions with those clients. A relationship is thus built up between the parties to address the needs of the client and to ensure a degree of client retention for the bank (Levesque \& MacDougall, 1996: 14). Relational factors play an important role in ensuring satisfied retail banking clients and in promoting a common understanding between the client and bank with regard to the bank's product and service offerings (Levesque \& MacDougall, 1996: 15, 19). In addition, the knowledge of bank staff can be used to identify, address and resolve client problems and complaints. The bank-client relationship improves and is more likely to occur in a branch than in a non-branch environment (Greenland, 1994: 21).

Fundamentally, a relationship-based approach enables bank staff to address problems associated with asymmetric information (Boot, 2000: 7). A branch outlet facilitates the relationship and allows information to be shared. Banks, through client-facing consultants, can determine spending patterns and the historical account relationship of clients (Koch \& MacDonald, 2003: 653). In effect, in reducing asymmetric information, the relationship simultaneously enables the bank to monitor the behaviour of the client.

\subsection{Choosing where to bank}

Besides having a relationship with its clients, a bank must consider what makes clients choose one particular bank over another. According to Lee \& Marlowe (2003: 66), convenience is strongly associated with bank account usage. However, they found that convenience may mean different things to different categories of consumers, depending largely on their views on delivery channel interaction. They found that multi-account holding consumers regard convenience as the most important factor and that the more products a client holds (especially assets), the greater the emphasis on having a personal relationship with the bank (Lee \& Marlowe, 2003: 66-67).

A study by Devlin \& Gerrard (2004) analysed the changing trends in choice criteria when people select a retail bank. They found that the greatest influence, over time, related to the incentives that banks offer clients (Devlin \& Gerrard, 2004: 20). In other words, a bank needs to create some form of incentive for clients to choose it. Recommendations made through word-of-mouth were also found to be important contributors (Devlin \& Gerrard, 2004: 21). The authors suggest that this reliance on credence qualities (in this case, seeking credibility through valued personal relationships) could indicate the clients' perception that retail services are viewed as commodity offerings. So-called "economic factors", including interest paid and fees levied and a wider product range, have in recent times 
also become more prevalent choice criteria (Devlin \& Gerrard, 2004: 25). They conclude that the changing trends in choice criteria require banks to keep up with changing times and to continue to monitor client behaviour (Devlin \& Gerrard, 2004: 24). A further study by Gerrard and Cunningham (1999: 34) concluded that multiple bank customers tend to be well educated. The study identified a positive relationship between the level of income earned and the tendency to have multiple banking relationships. It follows that, in the South African context, the unbanked would not engage in multiple banking relationships.

\subsection{The dynamics of personal interaction through branches}

A branch outlet reflects, amongst other things, the service culture, brand and image the bank wants to portray to the public. These are important considerations when forming client relationships. Branches should offer convenience and provide support to clients, given the complexity and perceived risks associated with financial services (Babakus, Eroglu \& Yavas, 2004: 462; Rose \& Hudgins, 2005: 645). Branch outlets also represent a tangible reference for clients with which they can associate themselves and by which they can judge the bank (Greenland, 1994: 22). Ultimately, they are service outlets for clients who have developed a strong sales orientation in recent years (Rose \& Hudgins, 2005: 658).

When the decision to build a branch is made, several considerations must take place. Alvarez (2005) indicates that a branch must "connect with the local community". Communication technologies such as strategically placed plasma screens in branches are both informative and educational. Branches should also offer clients an atmosphere of confidentiality and privacy. The internal design should facilitate an efficient working environment (Rose \& Hudgins, 2005: 654). The site chosen for the branch must ensure maximum visibility and accessibility to clients (Rose \& Hudgins, 2005: 655).

Front-office staff must ensure that faceto-face interaction occurs with clients (Mols, Bukh \& Nielsen, 1999: 41). Their knowledge and expertise should enable clients to use the products and services provided by the bank. Especially in view of the sensitive nature of personal financial matters, face-to-face contact with skilled bank staff in a private and confidential setting such as a branch contributes to a relationship based on trust. Indeed, trust is seen as very important when dealing with the unbanked.

\subsection{Remote interaction through electronic-banking channels}

Although a branch outlet offers face-to-face contact between bank staff and clients, ATMs, SSTs, Internet and telephone banking facilities offer a cheaper alternative to interacting with clients face-to-face. Greenland (1995: 12), for example, indicates that technological advances have reduced branch sizes and costs. Branches are becoming a one-stop financial services channel, using retail consultants, personal financial planners, tellers, and on-site electronic channels. Turban, King, Lee, Warkentin and Chung (2002: 86) refer to this as the "click-andmortar" model. Needless to say, face-to-face contact is important even for technology-savvy clients so that bank products and services can be customised to their needs (Alvarez, 2005).

The introduction of new e-based technologies may, however, create uncertainty in clients. Ernst and Young (1994) indicate that the integration and introduction of new technologies should follow a step-by-step process due to its being safer and enabling the testing of new technologies. This has made it necessary for banks to search for strategic leaps in technology implementation, due to the constant competition from non-bank competitors such as retailers (Watkins 2000: 65). Nevertheless, electronic channels offer convenience and can reduce transaction time (Mols et al., 1999: 39). More importantly, due to clients becoming more autonomous and demanding in their behaviour, electronic channels allow clients reduced interaction with the physical bank. It remains to be seen (bearing in mind how limited information that is publicly available on the unbanked is) exactly what the preferences of the unbanked are, and, perhaps more importantly, 
how these preferences change over time as the previously unbanked become regular users of bank products and services.

\subsection{Banking the unbanked: personal or remote interaction?}

The literature provides valuable insights on how to service clients. However, it appears, primarily from the Finscope surveys, that the needs and requirements of the previously unbanked are different from those of traditional banking clients. For example, for banks to build relationships with clients, multiple interactions between the two parties must occur. However, the rural unbanked are typically situated in extremely remote rural areas, making it difficult for them to interact continuously with the bank, especially on a face-to-face basis. This is unfortunate and costly for the unbanked, as face-to-face interaction enables banks to use the knowledge of bank staff to identify and resolve problems that the unbanked may have. A faceto-face approach also enables a bank to monitor the behavioural characteristics of formerly unbanked clients and reduce the perceived risks that the financial industry must address with this market.

Furthermore, through multiple interactions, the perceptions of risk that the unbanked have concerning bank products and services are also mitigated. Some form of personal face-to-face interaction enables bank consultants to explain (for example) the application process to the rural unbanked. The 2006 Finscope study showed that 65 per cent of this market indicated that they had not heard of or did not understand the banks' application process (Finscope South Africa, 2006: 27). Personal interaction by bank staff can therefore be seen as an important condition to educate the unbanked. This notion of a type of "mutual risk mitigation" of the relationship by both parties supports the fact that the unbanked would be more inclined to enter into a relationship with a bank than with any other financial services provider (Finscope South Africa, 2006: 28-29).

It therefore follows that personal, face-to-face interaction may reduce problems regarding communication, safety, security, status and respect associated with being unbanked. Because the unbanked are less financially literate and have lower levels of sustainable income, they are also less inclined to have multiple banking relationships. Cost considerations are therefore central to how they decide to become banked: it has already been shown that the four main reasons cited for not having a bank account all relate to poor financial conditions (Finscope South Africa, 2006: 29). Indeed, it is often already expensive for the unbanked just to interact with any form of bank representation, mainly due to their remoteness from any such representation. It should therefore be noted that the issue of interaction is indeed a problem area for both banks and the unbanked. Just as a bank has to consider costs and logistics, an unbanked person must consider carefully how and when he or she can visit a bank. In effect, banks must bear in mind that it is expensive for the unbanked to interact with a bank. Besides transaction costs at the bank, additional costs associated with transport or taking a day off work may also apply, because some rural areas are so remote from any facilities. These constraints prevent the unbanked from engaging in multiple interactions with their banks.

Clearly there is a dilemma when banks want to service the unbanked: should they pursue a distribution channel strategy that is relatively more expensive through a physical branch presence or a cheaper electronic-based presence? Their physical branch presence facilitates relationship-building through consultants interacting on a face-to-face basis and enables the bank to contribute to financial literacy. By contrast, an electronic-based presence does not facilitate any personal interaction between bank consultants, but offers a less expensive option to both the bank and client. A strategy focusing exclusively on electronic channels assumes that the unbanked are generally more autonomous in their understanding of bank terminology and process. This is clearly not always the case with the unbanked. A further problem is that the mere act of interacting with a bank is expensive for the unbanked - their remote location raises costly implications just for them to interact with the bank in the first place. Banks must therefore not only decide on the mode of interaction, but 
also to what extent it must deploy its services to the unbanked. Logistic considerations are therefore also important.

The next section considers what the Big4 are currently doing to address these concerns. In particular, what distribution channel strategies are they using? How are banks trying to improve the levels of financial literacy amongst the rural unbanked?

\section{5}

\section{The current interaction strategies adopted by the Big4}

Several countries have identified the problems associated with banking the unbanked and some large banks have expanded their operations to developing countries where the problem exists. Banks such as Barclays, Standard Chartered and HSBC have an extensive presence in developing countries, where a large proportion of the population are unbanked. As this section will indicate, the challenges they face in banking the unbanked are consistent with those in South Africa. For instance, even in a developed country such as the USA, the financial education of underbanked clients, ${ }^{4}$ especially Hispanic immigrants, is a focus area of bank distribution strategy. Even tellers are empowered to crosssell and educate clients "at just the right time with just the right amount of information needed" (Herrmann, Schutte \& Schneider, 2008: 8). The findings of the Finscope studies in South Africa are very similar to those of a study by Tescher, Sawady and Kutner (2007: 4), who found that the underbanked in the USA were comfortable with the workings of the informal sector; safety and confidentiality of the physical setting are important for interaction with the bank; channels must be conveniently situated; innovative financial products that are not necessarily suitable for mainstream clients are preferred; and they have a desire to be financially literate. The study went further to state that "the underbanked perceive significant barriers to establishing banking relationships. By understanding who these consumers are and how they make decisions, banks can develop appropriate services for them and, in time, lasting relationships that are a win for both parties" (Tescher et al., 2007: 19).

The geographical inaccessibility of the unbanked is also considered a problem. For instance, in developing countries such as Pakistan, the remote geographical location of the unbanked has made local banks realise that they must be accessible to clients "without the burden of physical infrastructure investments" (Mas \& Kumar, 2008: 1). Mobile banking channels have become a viable alternative to traditional brick-and-mortar channels, because they are cheaper to maintain and thus provide a more geographically accessible contact point with the unbanked. Although statutory barriers may exist in some countries, a recent World Bank (2006) report indicated that postal networks are considered an alternative to providing access to financial services to the unbanked due to their geographical outreach. To name only a few, countries such as Botswana, Namibia, China, Sri Lanka, Hungary, Russia, India, Argentina and Brazil use their postal networks extensively to provide financial services to the poor and unbanked sectors of the population (World Bank, 2006: 13-17).

With this in mind, the next sub-section considers the interaction strategies of the Big4 South African retail banks.

\subsection{Banks have redefined their delivery channel approach towards the previously unbanked}

The Big4 have indicated that physical locations will be important in their retail strategies in general (PWC, 2005: 10). This is in line with the FSC's requirement that the financial sector must provide first-order retail products and services (FSC, 2005: 9) "through appropriate and accessible physical and electronic infrastructure". As a result, the Big4 have redefined and, in some instances, established strategies to bank the unbanked.

The banks realise the importance of aligning their distribution network and channels to the requirements of the rural unbanked. For instance, Standard Bank continues to review its distribution channel and product offering strategy to low-income clients (Standard Bank 
of South Africa, 2006a:19). The bank has identified the black middle class as a segment of great opportunity, spearheaded by a "focused strategy" implemented in 2004 to gain market share (Standard Bank of South Africa, 2006a: 19). In 2006, Standard Bank implemented a new "branch delivery model" that encourages customer autonomy within branches (Standard Bank of South Africa, 2006a: 19).

Similarly, FNB regards improving branch infrastructure as important. In the 1990s, FNB realised that a total revamp of its branch operations was necessary and launched the socalled 'Banking2000' initiative that realigned FNB's retail strategy to adapt branch operations to be more conducive to technology in banking (Remenyi \& Cinnamond, 1996: 293). This initiative resulted in a reorganisation of the layout and structure of retail branches and the introduction of innovative information solutions (Remenyi \& Cinnamond, 1996: 314). In 2005, FNB branches were again revamped to allow easier customer navigation by creating specialised sales and service platforms to optimise processes to ensure faster service delivery (FirstRand, 2005: 32). In 2006, a further 112 branches were converted to the new retail design (FirstRand 2006: 34). These changes enable FNB constantly to re-position its branch network to reflect changes in demographics and retail and commercial developments in previously disadvantaged areas. For example, 24 per cent of all representation points are in these areas (FirstRand, 2006a: 34). Community banks also provide full service banking facilities to remote rural previously unbanked areas - so far, 27 have already been deployed (FirstRand, 2006a: 34).

In view of a changing South African banking environment and a poor retail-focused strategy aimed primarily at the more affluent upper-end of the retail market in urban areas (Nedcor, 2003: 46), Nedbank has undergone dramatic strategic realignment in recent years. This has resulted in the bank's changing focus from a "niche elite to mass aspirational" focused bank (Nedcor, 2004: 1). These changes are driven by the Strategic Recovery Programme implemented in 2004 (Nedbank Group, 2006a: 51). A noteworthy result has been the rebranding of approximately 144 People's Bank Ltd branches to Nedbank branches and a concerted effort to increase the number of new branches in growth and previously disadvantaged areas (Nedcor, 2004: 36; Nedbank Group, 2005: 29; Nedbank Group, 2006a: 55).

Like the other banks, ABSA focuses on increasing its reach in previously disadvantaged areas (ABSA, 2005: 157). In referring to the issue of accessibility of financial services to the unbanked, ABSA (2008) comments: "The challenge lies in educating the 'un-banked' sector (those individuals who have never used banking services before), providing products that are relevant and affordable to them, and increasing our group's physical footprint in communities where our services do not currently exist." Providing products and services that are relevant to the unbanked is clearly an important strategic imperative for ABSA. ABSA also regards the black middle class segment as a major strategic driver which it intends to target through an optimal mix of roving sales teams, branches and e-channels (ABSA, 2004: 120).

\subsection{The emergence of innovative non- traditional delivery channels}

Perhaps it is even more important to provide innovative solutions to achieve the FSC requirements than to increase the number of physical outlets in rural areas. Mobile or portable banks are offered by all four banks, and they all focus on representation in previously disadvantaged areas. An advantage of this mobility is that a bank is able to test the viability of previously unexplored disadvantaged areas (ABSA, 2004: 166; FirstRand, 2006a: 34; Standard Bank of South Africa, 2004: 15). These cost-efficient, prefabricated mobile banks typically offer the services found in full-scale branches and usually provide ATM facilities, tellers and sales consultants that interact directly with clients (FirstRand, 2004b: 6-7, 24; Nedbank Group, 2006b: 76; Standard Bank of South Africa, 2004: 15). Roving sales teams are also used to promote low-end products in remote rural areas (ABSA, 2004: 121; Nedbank Group, 2005: 29, 30). 
An innovative development is the mini-ATM used by FNB. This low-cost technological solution enables clients to conduct transactions in remote rural areas. Clients receive a "cash slip" that is presented to the storekeeper who "cashes" the transaction. In effect, the bank does not have to commit any cash to the ATM, as the risk is transferred to the respective store, which is also an FNB client. The mini-ATMs are strategically situated in areas that do not require full banking services and are low in transaction volumes (Kitten, 2005). An indication of the success of the mini-ATMs is the increase of over 21 per cent in their deployment during the period from 2004 to 2006 (FirstRand, 2004a: 24; FirstRand, 2006b: 122).

\subsection{Traditional delivery channels remain important}

The Big4 banks refer to branch outlets and ATMs as "points of representation". These are indicated in Table 1 below. Except in Standard Bank, the number of branches in the remaining three banks increased between 2004 and 2006. This was largely due to Standard Bank's efforts to consolidate business operations (Standard Bank of South Africa, 2006a: 19).

The number of Nedbank branches has remained relatively constant after decreasing slightly in 2005. As mentioned above, the Strategic Recovery Programme was the main reason for this. The restructuring programme was developed in three phases over three years, namely, "Fix" in 2005, "Consolidate" in 2006 and "Grow" in 2007 (Nedbank Group, 2006a: 51). The Fix and Consolidate phases led to a rebranding of People's Bank branches to Nedbank branches. This resulted in a substantial increase in the number of Nedbank branches in 2004, but, because there was duplication in a number of areas, 69 branches were closed (Nedbank Group, 2005: 7, 43). Nedbank uses the Pick ' $n$ Pay Go Banking branch network, so there were only 456 actual Nedbank-branded branches in 2006 (Nedbank Group, 2006a: 52). This is considerably lower than the number of branches of the other three banks. A consequence of this was the planned opening of an additional 400 outlets in 2007, 100 of which were planned for previously disadvantaged areas (Nedbank Group, 2006a: 55).

Table 1

The number of retail points of representation of the Big4 banks

\begin{tabular}{|l|c|c|c|c|c|c|}
\hline \multicolumn{1}{|c|}{ Bank } & \multicolumn{3}{c|}{ Branches } & \multicolumn{3}{c|}{ ATMs } \\
\hline & 2004 & 2005 & 2006 & 2004 & 2005 & 2006 \\
\hline ABSA & 668 & 675 & 749 & 4502 & 5078 & 7053 \\
\hline FNB & 646 & 667 & 680 & 2230 & 2405 & 2733 \\
\hline Nedbank & $763 \#$ & $750 \#$ & $764 \#$ & $1437^{*}$ & $1492^{*}$ & $1599 *$ \\
\hline Standard Bank & 741 & 746 & 712 & 3289 & 3768 & 4107 \\
\hline
\end{tabular}

\# includes retail branches and Pick ' $\mathrm{n}$ Pay outlets.

* includes Nedbank and Old Mutual Bank ATMs.

(Source: Various annual and sustainability reports of the Big4 for the period 2004 to 2006)

The number of staffed ABSA outlets increased over the three-year period. Prior to 2004, the number of outlets decreased substantially, mainly due to the consolidation of Volkskas, United, Allied and Trustbank into the single
ABSA brand in 1998 (ABSA, 2006b). In addition to FNB's committing to increasing its number of mobile banks and mini-ATMs to FSC target areas, 24 per cent of FNB branches already function in these areas (FirstRand, 2006b: 41). 
On the other hand, the growth in the number of ATMs in rural and previously disadvantaged areas is central to the current and future distribution strategies of each bank. Table 1 shows that all four banks have significantly increased their ATM representation.

ABSA has considerably more ATMs than any other bank, although the figures provided for FNB do not include the 1455 mini-ATMs. ABSA is clearly benefiting from the extensive infrastructure network it has inherited from the four merged brands from the 1990s, as well as from being widely regarded as the market leader in retail banking. In 2004, ABSA indicated that of the new ATMs planned for 2005, as many as 70 per cent would be in areas that support the black market segment (ABSA, 2004: 166).

Nedbank planned to upgrade and increase its ATM network by 50 per cent between 2006 and 2008. Of the 147 ATMs installed during the second half of 2006, 50 per cent were in previously disadvantaged areas (Nedbank Group, 2006a: 55).

Standard Bank constantly reviews its distribution channel strategy aimed at lowincome clients and has reduced its ATM costs to enable ATM deployment to areas that were previously too costly (Standard Bank of South Africa, 2006b).

Similarly, FNB attempts to encourage its clients to migrate to cheaper ATM facilities through its pricing strategy (FirstRand 2006a, 6). The mini-ATMs offered also contribute to cost efficiencies for the bank and are effective in providing representation in remote rural areas (FirstRand 2006a: 11).

The emergence of these innovative channel solutions reflects the risk that is still associated with banking the unbanked. The mobile nature of branches or ATMs enables banks to test the viability of rural areas and move to alternative areas if the costs outweigh the income generated. Anecdotal evidence suggests that the success of a mobile bank may hinge on as little as merely moving the unit across the street or a few kilometres down the road. This highlights the fact that the financial industry and banks in particular still have a lot to learn about the behavioural and indeed cultural characteristics of the unbanked in rural areas.

\subsection{Financial education of the unbanked is vital}

All four banks regard the promotion of basic financial literacy as important. For example, FNB's financial literacy and education programmes are "designed to be in simple language, informative, clear and educational" (FirstRand, 2006b: 113) Standard Bank conducts an in-depth needs analysis during the initial interview with a client and holds informal "imbizo" gatherings at high traffic taxi and train stations (Standard Bank of South Africa, 2006b).

Language barriers are also addressed by the distribution channels. This is particularly evident at ATMs, because the banks communicate with clients in several of the eleven official languages in their electronic channels. The Nedbank Group (2006b: 47) has also conducted market research by speaking "directly to regional target markets in their language of choice to really position Nedbank's commitment to 'make things happen' for all". This indicates that the positioning of the brand is just as important to the bank as being able to communicate in the mother tongues of the unbanked.

Initiatives are also conducted in banking halls to explain the workings of bank products and services. It is noticeable that educating the unbanked is central to these initiatives. For example, ABSA states that its "consumereducation drive... aims to empower people who have not used banking services before, by helping them understand what is available and how to access it...[to help] individuals to make informed decisions about the type of account and financial services that best suit their needs". Similarly, FNB states (FirstRand, 2006b: 41) that "basic financial awareness and the ability to make informed, sound financial decisions is the cornerstone of any effort to financially transform communities". A further indication of FNB's innovative approach is the literacy and education programmes focusing on, amongst other things, explaining the meaning of basic financial jargon and the responsibilities of home ownership in particular to FSC clients. The "Be Financially Smart" programme is presented on the radio and is being run in all eleven official languages (FirstRand, 2006b: 41). 
It remains to be seen what the impact of these initiatives on the previously disadvantaged will be. Generally speaking, the initiatives offered by all four banks are similar. Whether the unbanked decide to choose one bank over another may depend on the degree of association they feel with a particular bank's brand. It follows that the marketing and branding strategies chosen by each of the banks may well be an important precursor to attracting the unbanked. Along with a logistical presence, brand awareness is therefore critical.

\section{6}

\section{Discussion and recommendations}

The above analysis indicates that the large South African retail banks have begun to take into account the nature of the unbanked previously disadvantaged, as they are now using aspects of both personal and electronic channels to interact with them. This allows banks to minimise costs, whilst ensuring some form of personal interaction by bank staff with these clients. The mobility of the channels is indicative of the perceived risks associated with banking a market that has been avoided by the major financial institutions in the past. Mobility allows the bank the opportunity to gain valuable information on consumer and geographic dynamics without committing exorbitant capital to research and development on the one hand, and branch infrastructure on the other. This has enabled banks simultaneously to improve accessibility and promote financial literacy.

Although the 2006 Finscope survey established that the primary reason for a person's not having a Mzansi account was due to people's already being banked (Finscope South Africa, 2006: 30), banks can only be sure of the long-term benefits of building relationships with the unbanked over time. If they can establish such relationships, successfully banking the unbanked can become a prime example of how building relationships can be mutually beneficial in respect of promoting both profitability and financial literacy. If banks can successfully address the banking requirements of the unbanked through costeffective distribution channels, the potential for revenue growth is significant, due to the untapped nature of the market.

It may be important that banks define their relationships with this market segment as meaning something different from the generally accepted definition of their relationship with the formal market. For now, however, it appears that the large South African retail banks have adopted a somewhat cautionary approach to banking the mass market. This is understandable when one considers that this market segment has not been a focus area in the past.

It is clear that the banks realise the importance of providing innovative channels which allow access to banking for the unbanked. However, they need to establish whether the initiatives that have been put in place to promote consumer education really do add value to the lives of the unbanked. When they find the answer to this question, banks can adapt their product offerings to suit their and their clients' needs better. The resulting relationship will require a continuous process of reciprocal learning by both parties. The banks should see successfully banking this market as an opportunity to provide products with features the unbanked need, rather than products with features that resemble those offered to formal mainstream clients.

Furthermore, it is important that the Mzansi brand is associated with addressing the needs of the unbanked and does not merely dissipate into just another unsuccessful attempt by the banks to try to tap into the unbanked market. In order to do this, banks must ensure that they are aware of the changing behavioural dynamics of the unbanked and adapt accordingly. This is a continuous process that will require the constant co-ordination of management at both the decision-making and client-facing levels.

A cost-effective relationship that combines both modes of interaction currently appears to be the ideal approach to banking the unbanked - improving financial literacy through face-toface interaction of some sort, but retaining the electronic characteristics offered by the cheaper electronic-based services. In some instances the initial interactions with an unbanked client could require more personal interaction, compared to later in the relationship. Since there is a widespread lack of financial literacy and there 
are concerns about trust, personal interaction would orient the individual and create awareness about bank product functionality. As the relationship matures and financial literacy improves, the clients are able to "migrate" to electronic channels and rely less on personal interaction. FNB has adopted a strategy like this, encouraging clients to move to cheaper electronic channels (FirstRand, 2006b: 26).

Holisitically speaking, the Big4 appear to be making progress in banking the unbanked. Hawkins (2004: 201) indicates that South African banks' attempts to improve nonfinancial services to the low end of the market were initially slow, but the process appears to be gathering some momentum. The important question remains whether banks will continue to offer solutions that add value to the lives of the unbanked as their behavioural characteristics adapt to the continuous use of bank products and services. This endeavour should be seen as an ongoing process of product and service refinement on the part of the banking sector. Measuring these trends should be the focus of future research.

\section{7}

\section{Conclusion}

The findings of the study reveal that the large South African retail banks regard face-to-face interaction as crucial in banking the unbanked, but also realise the importance of testing the financial viability of unexplored rural areas and gaining consumer information through mobile channels. That said, banks have not disregarded electronic channels, primarily due to the lower costs of using such channels. Indeed, the mobile channels that are used mostly have ATMs and, with the assistance of on-site consultants, the unbanked are able to learn how to use the facilities. ATMs and their derivatives have also been strategically placed in rural areas. This suggests that the banks have realised that it is important not only to bank the unbanked through innovative channels, but also concurrently to develop consumer literacy in a manner that is financially feasible for both the bank and the unbanked. Banks are therefore following an integrated approach, using aspects of both personal and remote interaction. This strategy is predominantly due, firstly, to the current lack of information on trends in consumer behaviour towards banks in this market segment and, secondly, the importance of promoting financial literacy in this segment.

Although the study sheds some light on how the Big4 South African banks are currently approaching their interaction with the unbanked, it is clear that more research is needed. Since the Finscope surveys are the only recognised source of data on the South African unbanked, academics and business practitioners need to investigate the characteristics of the unbanked further to determine whether or not bank product and service offerings are indeed promoting financial inclusion and adding value to the lives of the unbanked. It follows that in order for this to occur, the behavioural trends among the unbanked towards banks, and in particular, the trends regarding their use of banking products and services must be documented. This is an effort that is not limited to the South African unbanked market (Herrmann et al., 2008: 8). With the challenges facing the South African financial industry at large, the temptation for banks is to prevent market access to this information, which will hinder opportunities to find solutions to the problem of banking the unbanked.

\section{Endnotes}

1. SSTs are electronic terminals that allow customers to do their banking on their own without the assistance of branch staff and include activities such as transferring funds between accounts and ordering cheque books (Rose \& Hudgins, 2005: 664). In recent times banks have integrated these functions into ATM functionality, although Nedbank still uses the terminals separately.

2. Several studies have highlighted the important link between financial inclusion and economic development. See, for example, Demirguc-Kunt, Beck and Honohan (2008).

3. This was confirmed by business practitioners within the financial industry at the International Quality and Productivity Centre (IQPC) conference entitled "Banking the underbanked", held in Johannesburg on 4 and 5 December 2007. 
4. The term "underbanked" typically refers to "consumers who have no more than one transaction account in a traditional financial institution" (Boyd \& Jacob, 2007: 6). So, although the unbanked would typically not have a bank account, they share similar characteristics.

\section{References}

ABSA 2004. Annual Report. [online] Available at: http://absa.co.za [Accessed 25 July 2005]. 2005. Annual report. [online] Available at: http://absa.co.za [Accessed 4 September 2006]. 2006a. Annual report. [online] Available at: http://absa.co.za [Accessed 31 May 2007]. 2006b. ABSA in context. [online] Available at: http://www.absa.co.za/ absacoza/content.jsp?VGN_C_I $\mathrm{D}=\mathrm{d}$ 9615591b1a4ff00VgnVCM100000ce17040aRCRD $\&$ VGN_CI_ID $=5$ b32515f3a2f1010VgnVCM100000ce 17040aRCRD [Accessed 31 May 2007]. 2008. Corporate citizenship, black economic empowerment, facts and current status. [online] Available at: http://www.absa.co.za/absacoza/content. jsp?VGN_C_ID=2b79bdb9fd48e010VgnVCM100000 3511060aRCRD\&VGN_CI_ID $=15 f 9 b d b 9 f d 48 e 010 \mathrm{~V}$ gnVCM1000003511060aRCRD\#Access_to_financial_ services [Accessed 5 February 2008].

ALVAREZ, E. 2005. Five common mistakes of branch building. US Banker, July: 56.

BABAKUS, E.; EROGLU, S. \& YAVAS, U. 2004.

Modelling consumers' choice behavior: an application in banking. Journal of Services Marketing, 18(6): $462-470$.

BOOT, A.W.A. 2000. Relationship banking: What do we know? Journal of Financial Intermediation, 9: 7-25. BOYD, C. \& JACOB, C. 2007. Mobile financial services and the underbanked: opportunities and challenges for Mbanking and Mpayments. Centre for Financial Services Innovation, April, [Online] Available at: http://www.cfsinnovation.com/topic-view-detail. php? category_id $=165 \&$ article_id $=2906$ [Accessed 5 February 2008].

DEMIRGUC-KUNT, A.; BECK, T. \& HONOHAN, P. 2008. Finance for all?: policies and pitfalls in expanding access. A World Bank Policy Research Report. Washington, District of Columbia.

DEVLIN, J.F. \& GERRARD, P. 2004. Choice criteria in retail banking: an analysis of trends. Journal of Strategic Marketing, 12 (March): 13-27.

ERNST AND YOUNG 1994. Choosing the right path to virtual banking. Ernst and Young and American banker special report on technology in banking. New York.
FALKENA, H.; DAVEL, G.; HAWKINS, P.; LLEWELLYN, D.; LUUS, C.; MASILELA, E.; PARR, G.; PIENAAR, J. \& SHAW, H. 2004. Competition in South African banking. Task group report for the National Treasury and the South African Reserve Bank, April.

FEASIBILITY 2005. The impact of the Dedicated Banks Bill on access to financial services. A Report prepared for the Finmark Trust, July.

FINANCIAL SECTOR CHARTER (FSC) 2003. The banking council. [Online] Available at: www.fscharter. co.za [Accessed 31 May 2007].

FINMARK TRUST 2005. Preliminary principles for expanding consumer financial literacy in $S A$. November. [Online] Available at: [http://www.finmark.org.za/ Research.aspx?uno $=3$ [Accessed 5 September 2006]. FINSCOPE 2003. Finmark Trust pilot study banking survey. [Online] Available at: http://www.finmark. org.za/Research.aspx? uno $=3$ [Accessed 5 September 2006].

FINSCOPE SOUTH AFRICA 2006. Survey highlights including FSM model. Finmark Trust, brochure. [Online] Available at: [http://www.finmark. org.za/ Research.aspx?uno=3 [Accessed on 31 May 2007]. FIRSTRAND 2004a. Annual report. [Online] Available at: [http://www. firstrand.co.za [Accessed on 25 July 2004].

2004b. Sustainability report. [Online] Available at: http://www. firstrand.co.za [Accessed on 25 July 2005].

2005. Annual report. [Online] Available at: http://www.firstrand.co.za [Accessed on 4 September 2006].

2006a. Annual report. [Online] Available at: http://www. firstrand.co.za [Accessed on 31 May 2007]. 2006b. Sustainability report. [Online] Available at: http://www. firstrand.co.za [Accessed on 31 May 2007]. GERRARD, P. \& CUNNINGHAM, J.B. 1999.

The multiple banking behaviour of Singaporeans. International Journal of Bank Marketing, 17(1): 26-35. GREENLAND, S.J. 1994. Rationalization and restructuring in the financial services sector. International Journal of Retail \& Distribution Management, 22(6): 21-28.

GREENLAND, S.J. 1995. Network management and the branch distribution channel. International Journal of Bank Marketing, 13(4): 12-18.

HAWKINS, P. 2004. South Africa's financial sector ten years on: performance since democracy. Development Southern Africa, 21(1), March: 179-204.

HERRMANN, M.J.; SCHUTTE, A. \& SCHNEIDER, R. 2008. Innovation trends in financial services to the 
underbanked. Centre for Financial Services Innovation, March, [Online] Available at: www.cfsinnovation. com/doc.php? load=/cfsi_innovationtrends_mar08.pdf [Accessed 3 March 2008].

KITTEN, T. 2005. Reaching the unbanked: Learning from South Africa's FIs. 26 May. [online] Available at: www.atmmarketplace.com/article.php?id $=5689$. [Accessed 5 May 2007].

KOCH, T.W. \& MACDONALD, S.S. 2003. Bank management $\left(5^{\text {th }}\right.$ ed.). Mason, Ohio: Thomson South Western.

LEE, J. \& MARLOWE, J. 2003. How consumers choose a financial institution: decision-making criteria and heuristics. International Journal of Bank Marketing, 21(2): 53-71.

LEVESQUE, T. \& MCDOUGALL, G.H.G. 1996. Determinants of customer satisfaction in retail banking. International Journal of Bank Marketing, 14(7): 12-20.

MAS, I. \& KUMAR, K. 2008. Banking on mobiles: why, how, for whom? CGAP Focus Note, 48, June, [Online] Available at: http://www.cgap.org /p/site/c/ template.rc/1.9.4400/ [Accessed 10 November 2008]. MOLS, N.P., BUKH, P.N.D. \& NIELSEN, J.F. 1999. Distribution channel strategies in Danish retail banking. International Journal of Retail \& Distribution Management, 27(1): 37-47.

PORTEOUS, D. 2004. Making financial markets work for the poor. Finmark Trust, October. [Online] Available at: http://www.finmark.org.za/Research. aspx?uno=3 [Accessed 31 May 2007].

PRICEWATERHOUSECOOPERS (PWC) 2005.

Strategic and emerging issues in South African banking.

[Online] Available at: www.pwc.com/za/ENG/ins-sol/ publ/tax/pwc_BankingSA2005.pdf

NEDCOR 2003. Annual report. [Online] Available at: http://www. nedbankgroup.co.za [Accessed 25 July 2005].

NEDCOR 2004. Annual report. [Online] Available at: http://www. nedbankgroup.co.za [Accessed 25 July 2005].

NEDBANK GROUP 2005. Annual report. [Online] Available at: http://www. nedbankgroup.co.za [Accessed 4 September 2006]. 2006a. Annual report. [Online] Available at: http://www. nedbankgroup.co.za [Accessed 31 May 2007]. 2006b. Sustainability report. [Online] Available at: http://www. nedbankgroup.co.za [Accessed 31 May 2007].

REMENYI, D. \& CINNAMOND, B. 1996. Banking 2000? Reengineering at the First National Bank of Southern Africa to create a branch of the future. Journal of Strategic Information Systems, 5: 293-316. ROSE, P.S. \& HUDGINS, S.C. 2005. Bank Management and financial services ( $6^{\text {th }}$ ed.). New York: McGraw-Hill. STANDARD BANK OF SOUTH AFRICA 2004. Annual report. [Online] Available at: [http://www. standardbank.co.za [Accessed 25 July 2005]. 2005. Annual report. [Online] Available at: http://www. standardbank.co.za [Accessed 4 September 2006].

2006a. Annual report. [Online] Available at: http://www. standardbank.co.za [Accessed 31 May 2007].

2006b. Stakeholder review. [online] Available at: http://www. standardbank.co.za/site/investor/sr 2006/sr/c_personal.htm. [Accessed 31 May 2007]. STAVINS, J. 1999. Checking accounts: What do banks offer and what do consumers value. New England Economic Review, March/April: 3-13.

TESCHER, J.; SAWADY, E. \& KUTNER, S. 2007. The power of experience in understanding the underbanked market. Centre for Financial Services Innovation, June, [Online] Available at www.

cfsinnovation.com/doc.php?load=/keybank_paper.pdf [Accessed 3 March 2008].

TURBAN, E.; KING, D.; LEE, J.; WARKENTIN, M. \& CHUNG, H.M. 2002. Electronic commerce 2002: $A$ managerial perspective (Int. ed.). Upper Saddle River, New Jersey: Pearson Education.

WATKINS, J. 2000. Is a step-by-step approach to change a viable option for the UK retail banking sector? Journal of Business Research, 47: 65-74. WORLD BANK 2006. The role of postal networks in expanding access to financial services. Global Information and Communication Technologies Department, Discussion paper 1, November. 